\title{
Electrochemical performance of hard carbon negative electrodes for ionic liquid-based sodium ion batteries over a wide temperature range
}

Changsheng Ding ${ }^{a}$, Toshiyuki Nohira ${ }^{\mathrm{b}, *}$, Rika Hagiwara $^{\mathrm{a}, *}$, Atsushi Fukunaga $^{\mathrm{c}}$, Shoichiro Sakai ${ }^{c}$ and Koji Nitta ${ }^{c}$

${ }^{a}$ Graduate School of Energy Science, Kyoto University, Sakyo-ku, Kyoto 606-8501, Japan

${ }^{\mathrm{b}}$ Institute of Advanced Energy, Kyoto University, Uji, Kyoto 611-0011, Japan

${ }^{c}$ Electronics \& Materials R\&D Laboratories, Sumitomo Electric Industries, Ltd., Konohanaku, Osaka 554-0024, Japan

* Corresponding authors. Tel.: +81 75753 5822; Fax: +81 757535906 .

E-mail addresses: nohira.toshiyuki.8r@kyoto-u.ac.jp (T. Nohira) hagiwara@energy.kyoto-u.ac.jp (R. Hagiwara) 


\begin{abstract}
Sodium ion batteries (SIBs) have been attracting much attention as promising next-generation energy storage devices for large-scale applications. The major safety issue with SIBs, which arises from the flammability and volatility of conventional organic solvent-based electrolytes, is resolved by adopting an ionic liquid (IL) electrolyte. However, there are only a few reports on the study of negative electrodes in ILs. Here, we report the electrochemical performance of a hard carbon (HC) negative electrode in $\mathrm{Na}[\mathrm{FSA}]-\left[\mathrm{C}_{3} \mathrm{C}_{1}\right.$ pyrr][FSA] (FSA = bis(fluorosulfonyl)amide, $\mathrm{C}_{3} \mathrm{C}_{1}$ pyrr $=\mathrm{N}$-methyl-N-propylpyrrolidinium) $\mathrm{IL}$ over a wide temperature range of $-10{ }^{\circ} \mathrm{C}$ to $90{ }^{\circ} \mathrm{C}$. High-temperature operation, which is realized for the first time by using an IL, can take full advantage of the high capacity of $\mathrm{HC}$ even at a very high discharge rate of $1000 \mathrm{~mA}(\mathrm{~g}-\mathrm{HC})^{-1}$ : the discharge capacity is $230 \mathrm{mAh}(\mathrm{g}-\mathrm{HC})^{-1}$ at 90 ${ }^{\circ} \mathrm{C}$ and $25 \mathrm{mAh}(\mathrm{g}-\mathrm{HC})^{-1}$ at $25^{\circ} \mathrm{C}$. Moreover, surprisingly stable cycleability is observed for the $\mathrm{HC}$ electrode at $90{ }^{\circ} \mathrm{C}$, i.e. a capacity retention ratio of $84 \%$ after 500 cycles. Finally, a high full-cell voltage of $2.8 \mathrm{~V}$ and stable full-cell operation with Coulombic efficiency higher than $99 \%$ are achieved for the first time when using $\mathrm{NaCrO}_{2}$ as the positive electrode at $90{ }^{\circ} \mathrm{C}$.
\end{abstract}

Keywords: Sodium secondary battery; Hard carbon negative electrode; Ionic liquid; Wide temperature range; Full-cell performance 


\section{Introduction}

Lithium ion batteries (LIBs) have been extensively researched and applied in the field of portable electronics, e.g. in mobile phones, cameras, and notebook computers, because of their high energy and power density.[1-4] LIBs have been also attracting interest for applications in electric vehicle systems and household storage cells, where there is a need for superior performance and large battery size. However, from the viewpoint of resource strategy, LIBs are unsuitable for use in large-scale electrical energy storage because of their relatively high cost and the uneven distribution of lithium sources. Sodium, on the other hand, is relatively less expensive and more abundant (sodium can be easily obtained from seawater or the earth's crust). Therefore, sodium ion batteries (SIBs) are considered promising alternatives to LIBs for large-scale energy storage.

Graphite has been widely used as the negative electrode in LIBs because of its high energy density and low cost. However, when used as the negative electrode in SIBs, graphite is electrochemically inactive, and only a limited number of sodium ions can be intercalated into graphite.[5] In recent years, many materials, including carbonaceous materials,[6-15] as well as $\mathrm{Na}_{2} \mathrm{Ti}_{3} \mathrm{O}_{7},[16-20] \quad \mathrm{Na}_{4} \mathrm{Ti}_{5} \mathrm{O}_{12},[21]$ $\mathrm{TiO}_{2},[22-24] \mathrm{SnO}_{2},[25,26]$ and alloys, [27-31] have been developed for use as negative electrode materials for SIBs. Among them, carbonaceous materials have attracted 
much attention because of their relatively high capacity, natural abundance, safety, and nontoxicity. Alcantara et al. investigated the performance of carbon black as the negative electrode material for SIBs, and obtained a reversible capacity of $200 \mathrm{mAh}$ $\mathrm{g}^{-1}$.[6] Alcantara et al. also used carbon microparticles as the negative electrode material and showed a maximum reversible capacity of $285 \mathrm{mAh} \mathrm{g}^{-1}$.[7] Cao et al. reported that hollow carbon nanowires showed a reversible capacity of $251 \mathrm{mAh} \mathrm{g} \mathrm{g}^{-1}$ and $82 \%$ capacity retention over 400 cycles at a current density of $50 \mathrm{~mA} \mathrm{~g}^{-1}$.[8] Tang et al. demonstrated that hollow carbon nanospheres possessed excellent cycling stability and rate capability, and showed a reversible capacity of $223 \mathrm{mAh} \mathrm{g}^{-1}$ at $50 \mathrm{~mA}$ $\mathrm{g}^{-1}$.[9] Recently, much attention has been paid to hard carbon (HC) because of its relatively high capacity. Komaba et al. investigated the electrochemical insertion of $\mathrm{Na}$ into $\mathrm{HC}$, and demonstrated reversible capacities of $220-250 \mathrm{mAh} \mathrm{g}^{-1}$ in different organic electrolytes at $25 \mathrm{~mA} \mathrm{~g}^{-1}$.[10] Zhao et al. reported a reversible capacity of 321 $\mathrm{mAh} \mathrm{g}^{-1}$ for an $\mathrm{HC}$ electrode at a current density of $20 \mathrm{~mA} \mathrm{~g}^{-1}$.[11] Ponrouch et al. synthesized HC by sugar pyrolysis and demonstrated that this material had a reversible capacity of $>300 \mathrm{~mA} \mathrm{~g}^{-1}$.[12] Hong et al. synthesized HC from biomass and found that porous $\mathrm{HC}$ exhibited a reversible capacity of $315 \mathrm{~mA} \mathrm{~g}^{-1}$ at $50 \mathrm{~mA} \mathrm{~g}^{-1}$.[13]

All the above studies were conducted in organic solvent-based electrolytes such as $\mathrm{NaClO}_{4} /$ propylene carbonate or ethylene carbonate solution, which are highly volatile 
and flammable and are hence unsuitable for use in the construction of large-scale safe batteries. Ionic liquids, which are generally non-flammable and have negligibly low volatility as well as high thermal and electrochemical stability, have been considered as safer electrolytes for SIBs when compared with the organic solvent-based electrolytes. $\mathrm{Na}[\mathrm{TFSA}$-Cs[TFSA] $(\mathrm{TFSA}=$ bis(trifluoromethylsulfonyl)amide), Na[FSA]-K[FSA] $\left(\mathrm{FSA}=\right.$ bis(fluorosulfonyl)amide), and $\mathrm{Na}[\mathrm{FSA}]-\left[\mathrm{C}_{3} \mathrm{C}_{1}\right.$ pyrr $][\mathrm{FSA}] \quad\left(\mathrm{C}_{3} \mathrm{C}_{1}\right.$ pyrr $=$ $N$-methyl- $N$-propylpyrrolidinium) ionic liquids have been reported as suitable electrolytes for sodium secondary batteries.[32-35] Among them, $\mathrm{Na}[\mathrm{FSA}]-\left[\mathrm{C}_{3} \mathrm{C}_{1}\right.$ pyrrr] $\left.] \mathrm{FSA}\right]$ ionic liquids can be operated in a wide temperature range and show better electrochemical performance.[34,35] In our previous study, we investigated the electrochemical performance of $\mathrm{HC}$ electrodes in Na[FSA]-K[FSA], $\mathrm{Na}[\mathrm{FSA}]-\left[\mathrm{C}_{3} \mathrm{C}_{1}\right.$ pyrr][FSA] and $\mathrm{Na}[\mathrm{FSA}]-\mathrm{K}[\mathrm{FSA}]-\left[\mathrm{C}_{3} \mathrm{C}_{1}\right.$ pyrr][FSA] ionic liquids at 90 ${ }^{\circ} \mathrm{C}$.[36] We found that ionic liquids containing $\mathrm{K}^{+}$ions, such as Na[FSA]-K[FSA] and $\mathrm{Na}[\mathrm{FSA}]-\mathrm{K}[\mathrm{FSA}]-\left[\mathrm{C}_{3} \mathrm{C}_{1}\right.$ pyrr][FSA], are not suitable for the use of $\mathrm{HC}$ electrodes because of the irreversible $\mathrm{K}^{+}$ion insertion into $\mathrm{HC}$. On the other hand, the $\mathrm{Na}[\mathrm{FSA}]-\left[\mathrm{C}_{3} \mathrm{C}_{1}\right.$ pyrr][FSA] ionic liquid was found to be suitable for the use of $\mathrm{HC}$ electrodes exhibiting a reversible capacity of $260 \mathrm{mAh} \mathrm{g}^{-1}$ at $90{ }^{\circ} \mathrm{C} .[36]$ However, there is no report on the temperature dependence of the electrochemical performance of the $\mathrm{HC}$ electrode in the $\mathrm{Na}[\mathrm{FSA}]-\left[\mathrm{C}_{3} \mathrm{C}_{1}\right.$ pyrr] [FSA] ionic liquid. We have also 
investigated the viscosity and ionic conductivity of the $\mathrm{Na}[\mathrm{FSA}]-\left[\mathrm{C}_{3} \mathrm{C}_{1}\right.$ pyrr][FSA] ionic liquids at different temperatures, and reported the effect of operation temperature on the electrochemical performance of $\mathrm{NaCrO}_{2}$ positive electrodes.[37] In the similar manner, it is worth investigating for the $\mathrm{HC}$ electrodes the role of high-temperature operation on improvement of the electrode performance as compared that observed during conventional room temperature operation. Therefore, in this study, the electrochemical performance of an $\mathrm{HC}$ electrode in $\mathrm{Na}[\mathrm{FSA}]-\left[\mathrm{C}_{3} \mathrm{C}_{1}\right.$ pyrrr $][\mathrm{FSA}]$ ionic liquid was investigated over a wide temperature range between $-10{ }^{\circ} \mathrm{C}$ and $90{ }^{\circ} \mathrm{C}$. Moreover, to demonstrate the practical applicability of $\mathrm{HC}$ electrode, a full cell was fabricated using $\mathrm{NaCrO}_{2}$ as the positive electrode, and its performance was investigated for the first time at $90^{\circ} \mathrm{C}$.

\section{Experimental}

\subsection{Materials}

Commercially available HC powders (Carbotron P S(F), Kureha Battery Materials Japan Co., Ltd.) were used without any purification or treatment. Na[FSA] (Mitsubishi Materials Electronic Chemicals Co., Ltd., Japan, >99.0\%) and $\left[\mathrm{C}_{3} \mathrm{C}_{1}\right.$ pyrr][FSA] (Kanto Chemical Co., Inc. Japan, >99.0\%) were dried under vacuum at $60{ }^{\circ} \mathrm{C}$ for $24 \mathrm{~h}$. Na[FSA]-[C $\mathrm{C}_{3} \mathrm{C}_{1}$ pyrr][FSA] ionic liquid electrolyte was prepared by mixing $\mathrm{Na}[\mathrm{FSA}]$ and $\left[\mathrm{C}_{3} \mathrm{C}_{1}\right.$ pyrr $][\mathrm{FSA}]$ in 2:8 molar ratio. Reagent-grade acetylene black (AB; Wako Pure Chemical Industries), 
polytetrafluoroethylene (PTFE; Sigma-Aldrich), $N$-methyl-2-pyrrolidone $\quad$ (NMP), polyamide-imide (PAI; SOXR-O, 18.96 wt\% NMP solution, Nippon Kodoshi Corporation, Japan) binder, and metallic sodium were used. $\mathrm{NaCrO}_{2}$ powders were synthesized by mixing $\mathrm{Na}_{2} \mathrm{CO}_{3}$ and $\mathrm{Cr}_{2} \mathrm{O}_{3}$ and baking the mixture at $850{ }^{\circ} \mathrm{C}$ for $5 \mathrm{~h}$ under Ar flow.

\subsection{Electrochemical characterization}

The HC electrodes were fabricated by a conventional coating method. A slurry consisting of HC (96 wt \%) and PAI (4 wt\%) in NMP was uniformly coated onto Al foil. The HC electrodes were dried in a vacuum line at $200{ }^{\circ} \mathrm{C}$ overnight before being transferred into an Ar-filled glove box. For preparation of the positive electrode, the $\mathrm{NaCrO}_{2}$ powders were mixed thoroughly with $\mathrm{AB}$ and PTFE in a weight ratio of 80:15:5, using a mortar and pestle. The obtained mixture was pressed onto an aluminium mesh at $300 \mathrm{MPa}$. Electrochemical characterization was performed using 2032 type coin cells. Half-cells were fabricated with HC for the working electrode and sodium foil for the counter electrode. A full cell with $\mathrm{HC}$ and $\mathrm{NaCrO}_{2}$ electrodes was also fabricated using a 2032-type coin cell. A glass fiber filter (Whatman, GF-A, 260 mm) was used as a separator. The electrodes and separators were vacuum-impregnated with $\mathrm{Na}[\mathrm{FSA}]-\left[\mathrm{C}_{3} \mathrm{C}_{1}\right.$ pyrr $][\mathrm{FSA}]$ at $60{ }^{\circ} \mathrm{C}$ before assembling the cells. These cells were assembled in an Ar-filled glove box (dew point $<-80^{\circ} \mathrm{C}$ ). Charge-discharge tests were conducted at constant current rates of $20-2000 \mathrm{~mA}(\mathrm{~g}-\mathrm{HC})^{-1}$ over the voltage range $0.005-1.5 \mathrm{~V}$ and temperature range -10 to $90{ }^{\circ} \mathrm{C}$. Electrochemical impedance measurements of the $\mathrm{Na} / \mathrm{HC}, \mathrm{Na} / \mathrm{Na}$, and 
$\mathrm{HC} / \mathrm{HC}$ cells were performed in the frequency range of $500 \mathrm{kHz}$ to $100 \mathrm{mHz}$ with an $\mathrm{AC}$ voltage signal of $10 \mathrm{mV}$.

\section{Results and discussion}

The charge-discharge curves of the $\mathrm{HC}$ electrode measured at $90{ }^{\circ} \mathrm{C}$ with a current rate of $20 \mathrm{~mA}(\mathrm{~g}-\mathrm{HC})^{-1}$ are shown in Fig. 1. In the first cycle, a plateau is seen in the voltage range of 1.2-1.4 $\mathrm{V}$ during the charge process. The plateau at about $0.1 \mathrm{~V}$ in the charge-discharge curves corresponds to the insertion/ extraction of $\mathrm{Na}$ ions into/from HC. In the first cycle, the HC electrode exhibits a charge capacity of 353 mAh $(\mathrm{g}-\mathrm{HC})^{-1}$ and a discharge capacity of $277 \mathrm{mAh}(\mathrm{g}-\mathrm{HC})^{-1}$, showing $78.5 \%$ initial Coulombic efficiency. The irreversible capacity in the first cycle would be attributed to the formation of solid electrolyte interphase (SEI) on the surface of the HC electrode. In the subsequent cycles, the $\mathrm{HC}$ electrode shows a reversible discharge capacity of about 274 mAh $(\mathrm{g}-\mathrm{HC})^{-1}$.

To investigate the effect of operation temperature, charge-discharge tests were performed for the $\mathrm{Na} / \mathrm{HC}$ half-cell at -10 to $90{ }^{\circ} \mathrm{C}$. Fig. 2 shows the charge-discharge curves at a current rate of $20 \mathrm{~mA}(\mathrm{~g}-\mathrm{HC})^{-1}$. The $\mathrm{HC}$ electrode exhibits a discharge capacity of $193 \mathrm{mAh}(\mathrm{g}-\mathrm{HC})^{-1}$ at $25^{\circ} \mathrm{C}$, corresponding to about $70 \%$ of the initial discharge capacity at $90{ }^{\circ} \mathrm{C}$. At temperatures above $25^{\circ} \mathrm{C}$, the shapes of the charge-discharge curves are similar, and a plateau appears at voltages below $0.2 \mathrm{~V}$. 
However, the plateau disappears at temperatures below $25^{\circ} \mathrm{C}$. Naturally, the capacity decreases largely below $25^{\circ} \mathrm{C}$. The discharge capacities are 48 and $10 \mathrm{mAh}(\mathrm{g}-\mathrm{HC})^{-1}$ at 0 and $-10{ }^{\circ} \mathrm{C}$, respectively.

The lower capacity of the $\mathrm{Na} / \mathrm{HC}$ half-cell at low temperatures indicates the high internal resistance. The possible reasons for this are the reduced ionic conductivity, limited diffusivity of sodium ions in $\mathrm{HC}$, and increased charge-transfer resistance at either the $\mathrm{HC}$ or sodium metal. For a better understanding of the effect of operation temperature on capacity, electrochemical impedance measurements were carried out for the $\mathrm{Na} / \mathrm{HC}, \mathrm{Na} / \mathrm{Na}$, and $\mathrm{HC} / \mathrm{HC}$ cells at $0-90{ }^{\circ} \mathrm{C}$. Fig. 3a shows the impedance spectra of the $\mathrm{Na} / \mathrm{HC}$ cell at $0-90{ }^{\circ} \mathrm{C}$. It can be seen that the resistance of the $\mathrm{Na} / \mathrm{HC}$ cell increases with decreasing temperature, especially at temperatures below $25{ }^{\circ} \mathrm{C}$. The high-frequency limit is the electrolyte resistance $(R e)$. The semicircle at the middle frequency corresponds to the charge-transfer process at the electrode/electrolyte interface. Since the charge-transfer resistance $(R \mathrm{ct})$ is much larger than $R \mathrm{e}$, the cell resistance mainly results from $R$ ct. The $R$ ct value increases with decreasing operation temperature, indicating significant sensitivity to temperature. Figs. $3 \mathrm{~b}$ and $3 \mathrm{c}$ show the impedance spectra of the $\mathrm{Na} / \mathrm{Na}$ and $\mathrm{HC} / \mathrm{HC}$ symmetric cells at different temperatures. The Rct value for the Na electrode is much larger than that for the HC electrode; further, $R \mathrm{ct}$ for the Na electrode increases quickly at temperatures below $0{ }^{\circ} \mathrm{C}$. This 
indicates that the major component of $R \mathrm{ct}$ in the $\mathrm{Na} / \mathrm{HC}$ cell originates from the $\mathrm{Na}$ counter electrode, especially at lower temperatures.

Fig. 4 shows the rate performance of the $\mathrm{HC}$ electrode at $25-90{ }^{\circ} \mathrm{C}$. The charge-discharge curves at $90{ }^{\circ} \mathrm{C}$ for different current rates of $20-2000 \mathrm{~mA}(\mathrm{~g}-\mathrm{HC})^{-1}$ are shown in Fig. 4a. With an increase in the current rate, the general shape of the charge-discharge curves remains unchanged, and all the curves have a plateau at voltages below $0.2 \mathrm{~V}$. However, the capacity decreases gradually with an increase in the current rate. Fig. $4 \mathrm{~b}$ shows the rate capability of the $\mathrm{HC}$ electrode at $90{ }^{\circ} \mathrm{C}$. The discharge capacity at a current rate of $200 \mathrm{~mA}(\mathrm{~g}-\mathrm{HC})^{-1}$ is $261 \mathrm{mAh}(\mathrm{g}-\mathrm{HC})^{-1}$, which is about $94 \%$ of the initial capacity at $20 \mathrm{~mA}(\mathrm{~g}-\mathrm{HC})^{-1}$. Surprisingly, at a very high current rate of $1000 \mathrm{~mA}(\mathrm{~g}-\mathrm{HC})^{-1}$, the discharge capacity is maintained at $230 \mathrm{mAh}$ $(\mathrm{g}-\mathrm{HC})^{-1}$, corresponding to about $82 \%$ of the initial capacity. For HC electrodes operated in organic solvent-based electrolytes at room temperature, the capacity retention ratio is less than $50 \%$ at high current rate of large than $500 \mathrm{~mA} \mathrm{~g}^{-1}$.[13] The high capacity retention ratio in the present study is attributed to the high $\mathrm{Na}^{+}$ion conductivity of $\mathrm{Na}[\mathrm{FSA}]-\left[\mathrm{C}_{3} \mathrm{C}_{1}\right.$ pyrr] $[\mathrm{FSA}]$ ionic liquid at $90{ }^{\circ} \mathrm{C}$.[35] Except for the initial few cycles, the Coulombic efficiencies are higher than 99\%. After cycling at high currents, the discharge capacity recovers to the original value at a low current rate, indicating good tolerance for the rapid $\mathrm{Na}$ ion insertion and extraction. Fig $4 \mathrm{c}$ 
compares the rate capabilities of the $\mathrm{HC}$ electrode at 25,50 , and $90{ }^{\circ} \mathrm{C}$. The results clearly show that the $\mathrm{HC}$ electrode exhibits better high-rate capability at high operation temperatures. At low operation temperatures, the $\mathrm{C} / \mathrm{C}_{0}$ ratio $(\mathrm{C}$ : discharge capacity at a given current rate; $\mathrm{C}_{0}$ : discharge capacity at a current rate of $20 \mathrm{~mA} \mathrm{~g}^{-1}$ ) decreases quickly with an increase in the current rate. At $25^{\circ} \mathrm{C}$, the capacity retention is about $63 \%$ and $23 \%$ for current rates of 50 and $200 \mathrm{~mA}(\mathrm{~g}-\mathrm{HC})^{-1}$, respectively. At high temperature of $90^{\circ} \mathrm{C}$, the ionic liquid has a high conductivity and the cell shows a low charge-transfer resistance. In contrast, the conductivity is low and the charge-transfer resistance is high at low temperature of $25{ }^{\circ} \mathrm{C}$, which limits the rapid insertion/de-insertion of sodium. Thus, the HC electrode has better high-rate capability at high operation temperatures.

Fig. 5 shows the cycling performance of the $\mathrm{HC}$ electrode with a constant current rate of $200 \mathrm{~mA}(\mathrm{~g}-\mathrm{HC})^{-1}$ at 25 and $90{ }^{\circ} \mathrm{C}$. At $90{ }^{\circ} \mathrm{C}$, the discharge capacity decreases gradually, and a reversible capacity of $229 \mathrm{mAh}(\mathrm{g}-\mathrm{HC})^{-1}$ is retained after 500 cycles, corresponding to a capacity retention ratio of $84 \%$. Except for the initial few cycles, the Coulombic efficiencies are higher than $99 \%$. At $25{ }^{\circ} \mathrm{C}$, the discharge capacity increases gradually before 100 cycles and then remains almost constant until 500 cycles. The Coulombic efficiencies are also higher than $99 \%$ except for the initial few cycles. This indicates that the $\mathrm{HC}$ electrode is stably operated at $25-90{ }^{\circ} \mathrm{C}$. 
Finally, the charge-discharge performance of a coin-type full SIB using HC as the negative electrode and $\mathrm{NaCrO}_{2}$ as the positive electrode is investigated at $90{ }^{\circ} \mathrm{C}$. A $\mathrm{Na} / \mathrm{NaCrO}_{2}$ half-cell has been shown to exhibit a high reversible capacity of about 120 mAh $\left(\mathrm{g}-\mathrm{NaCrO}_{2}\right)^{-1}$ between 2.5 and $3.5 \mathrm{~V}$ at $90{ }^{\circ} \mathrm{C} .[37]$ Fig. 6 shows the charge-discharge curves of an $\mathrm{HC} / \mathrm{NaCrO}_{2}$ full cell between 1.5 and $3.5 \mathrm{~V}$ at $90{ }^{\circ} \mathrm{C}$. Several voltage plateaus are distinguishable in the charge-discharge curves, which are ascribed to the phase transitions of the $\mathrm{NaCrO}_{2}$ electrode.[38, 39] The $\mathrm{HC} / \mathrm{NaCrO}_{2}$ full cell exhibits a charge capacity of $326 \mathrm{mAh}(\mathrm{g}-\mathrm{HC})^{-1}$ and a discharge capacity of 263 mAh $(\mathrm{g}-\mathrm{HC})^{-1}$ in the first cycle. The irreversible capacity in the first cycle can be attributed to SEI formation on the surface of the HC electrode, as discussed above. In the subsequent cycle, the full cell shows a reversible discharge capacity of about 260 mAh $(\mathrm{g}-\mathrm{HC})^{-1}$ with a Coulombic efficiency of more than $99 \%$. The discharge capacity of the $\mathrm{HC} / \mathrm{NaCrO}_{2}$ full cell is higher than that of the $\mathrm{HC} / \mathrm{NaNi}_{0.5} \mathrm{Mn}_{0.5} \mathrm{O}_{2}$ full cell using organic solvent-based electrolyte,[10] indicating that the $\mathrm{HC}$ electrode shows better electrochemical performance in the $\mathrm{Na}[\mathrm{FSA}]-\left[\mathrm{C}_{3} \mathrm{C}_{1}\right.$ pyrr][FSA] ionic liquid electrolyte. This is due to the high $\mathrm{Na}+$ ion conductivity of $\mathrm{Na}$ [FSA $]-\left[\mathrm{C}_{3} \mathrm{C}_{1}\right.$ pyrr][FSA] ionic liquid at high temperature.[35] Since the HC electrode exhibited good cyclability with a capacity retention of $84 \%$ after 500 cycles, as shown in Fig.5, the full cell is well expected to have good cyclability. We are now investigating the performances, e.g., 
energy density, power density and cyclability, for several types of full cells at $25-90{ }^{\circ} \mathrm{C}$, which will be reported in the near future.

\section{Conclusions}

The electrochemical performance of an $\mathrm{HC}$ electrode in $\mathrm{Na}[\mathrm{FSA}]-\left[\mathrm{C}_{3} \mathrm{C}_{1}\right.$ pyrr][FSA] ionic liquid has been investigated in detail over the temperature range -10 to $90{ }^{\circ} \mathrm{C}$. The operation temperature strongly affects the electrochemical performance of the $\mathrm{HC}$ electrode. The HC electrode shows a reversible discharge capacity of $274 \mathrm{mAh}$ $(\mathrm{g}-\mathrm{HC})^{-1}$ at $90{ }^{\circ} \mathrm{C}$, which decreases rapidly to $48 \mathrm{mAh}(\mathrm{g}-\mathrm{HC})^{-1}$ at $0{ }^{\circ} \mathrm{C}$. This result implies that the HC electrode is more suitable for operating at high temperatures. The HC electrode shows better rate capability at high operation temperatures. An $\mathrm{HC} / \mathrm{NaCrO}_{2}$ full cell shows a high reversible discharge capacity of about $260 \mathrm{mAh}$ $(\mathrm{g}-\mathrm{HC})^{-1}$ at $90{ }^{\circ} \mathrm{C}$, which indicates that the $\mathrm{HC}$ electrode is a promising, safe negative electrode for ionic liquid-based SIBs. 


\section{Acknowledgements}

This study was partly supported by the Advanced Low Carbon Technology Research and Development Program (ALCA, No. 3428) of Japan Science and Technology Agency (JST), and the Elements Strategy for Catalysts and Batteries (ESICB) program of the Japanese Ministry of Education, Culture, Sports, Science and Technology (MEXT).

\section{References}

[1] R. Mukherjee, R. Krishnan, T.-M. Lu, N. Koratkar, Nanostructured electrodes for high-power lithium ion batteries, Nano Energy, 1 (2012) 518-533.

[2] R. Marom, S.F. Amalraj, N. Leifer, D. Jacob, D. Aurbach, A review of advanced and practical lithium battery materials, Journal of Materials Chemistry, 21 (2011) 9938.

[3] J.W. Fergus, Recent developments in cathode materials for lithium ion batteries, J Power Sources, 195 (2010) 939-954.

[4] Y. Wang, G. Cao, Developments in Nanostructured Cathode Materials for High-Performance Lithium-Ion Batteries, Advanced Materials, 20 (2008) 2251-2269.

[5] D.A. Stevens, J.R. Dahn, The Mechanisms of Lithium and Sodium Insertion in Carbon Materials, Journal of The Electrochemical Society, 148 (2001) A803. 
[6] R. Alcantara, J.M. Jimenez-Mateos, P. Lavela, J.L. Tirado, Carbon black: a promising electrode material for sodium-ion batteries Electrochem Commun, 3 (2001) 639-642.

[7] R. Alcantara, P. Lavela, G.F. Ortiz, J.L. Tirado, Carbon microspheres obtained from resorcinol-formaldehyde as high-capacity electrodes for sodium-ion batteries, Electrochem Solid St, 8 (2005) A222-A225.

[8] Y.L. Cao, L.F. Xiao, M.L. Sushko, W. Wang, B. Schwenzer, J. Xiao, Z.M. Nie, L.V. Saraf, Z.G. Yang, J. Liu, Sodium Ion Insertion in Hollow Carbon Nanowires for Battery Applications, Nano Lett, 12 (2012) 3783-3787.

[9] K. Tang, L.J. Fu, R.J. White, L.H. Yu, M.M. Titirici, M. Antonietti, J. Maier, Hollow Carbon Nanospheres with Superior Rate Capability for Sodium-Based Batteries, Adv Energy Mater, 2 (2012) 873-877.

[10] S. Komaba, W. Murata, T. Ishikawa, N. Yabuuchi, T. Ozeki, T. Nakayama, A. Ogata, K. Gotoh, K. Fujiwara, Electrochemical $\mathrm{Na}$ Insertion and Solid Electrolyte Interphase for Hard-Carbon Electrodes and Application to Na-Ion Batteries, Adv Funct Mater, 21 (2011) $3859-3867$

[11] J. Zhao, L.W. Zhao, K. Chihara, S. Okada, J. Yamaki, S. Matsumoto, S. Kuze, K. Nakane, Electrochemical and thermal properties of hard carbon-type anodes for Na-ion batteries, J Power Sources, 244 (2013) 752-757. 
[12] A. Ponrouch, A.R. Goni, M.R. Palacin, High capacity hard carbon anodes for sodium ion batteries in additive free electrolyte, Electrochem Commun, 27 (2013) 85-88.

[13] K.-1. Hong, L. Qie, R. Zeng, Z.-q. Yi, W. Zhang, D. Wang, W. Yin, C. Wu, Q.-j. Fan, W.-x. Zhang, Y.-h. Huang, Biomass derived hard carbon used as a high performance anode material for sodium ion batteries, Journal of Materials Chemistry A, 2 (2014) 12733-12738.

[14] J. Ding, H.L. Wang, Z. Li, A. Kohandehghan, K. Cui, Z.W. Xu, B. Zahiri, X.H. Tan, E.M. Lotfabad, B.C. Olsen, D. Mitlin, Carbon Nanosheet Frameworks Derived from Peat Moss as High Performance Sodium Ion Battery Anodes, Acs Nano, 7 (2013) 11004-11015.

[15] D.A. Stevens, J.R. Dahn, High capacity anode materials for rechargeable sodium-ion batteries, Journal of the Electrochemical Society, 147 (2000) 1271-1273.

[16] P. Senguttuvan, G. Rousse, V. Seznec, J.-M. Tarascon, M.R. Palacín, Na2Ti3O7: Lowest Voltage Ever Reported Oxide Insertion Electrode for Sodium Ion Batteries, Chemistry of Materials, 23 (2011) 4109-4111.

[17] W. Wang, C.J. Yu, Y.J. Liu, J.G. Hou, H.M. Zhu, S.Q. Jiao, Single crystalline Na2Ti3O7 rods as an anode material for sodium-ion batteries, Rsc Adv, 3 (2013) 1041-1044.

[18] W. Wang, C. Yu, Z. Lin, J. Hou, H. Zhu, S. Jiao, Microspheric Na2Ti3O7 consisting of tiny nanotubes: an anode material for sodium-ion batteries with ultrafast charge-discharge rates, Nanoscale, 5 (2013) 594-599. 
[19] A. Rudola, K. Saravanan, C.W. Mason, P. Balaya, Na2Ti3O7: an intercalation based anode for sodium-ion battery applications, Journal of Materials Chemistry A, 1 (2013) 2653.

[20] H. Pan, X. Lu, X. Yu, Y.-S. Hu, H. Li, X.-Q. Yang, L. Chen, Sodium Storage and Transport Properties in Layered Na2Ti3O7for Room-Temperature Sodium-Ion Batteries, Adv Energy Mater, 3 (2013) 1186-1194.

[21] S.H. Woo, Y. Park, W.Y. Choi, N.S. Choi, S. Nam, B. Park, K.T. Lee, Trigonal Na4Ti5O12 Phase as an Intercalation Host for Rechargeable Batteries, Journal of the Electrochemical Society, 159 (2012) A2016-A2023.

[22] H. Xiong, M.D. Slater, M. Balasubramanian, C.S. Johnson, T. Rajh, Amorphous TiO2Nanotube Anode for Rechargeable Sodium Ion Batteries, The Journal of Physical Chemistry Letters, 2 (2011) 2560-2565.

[23] Y. Xu, E.M. Lotfabad, H. Wang, B. Farbod, Z. Xu, A. Kohandehghan, D. Mitlin, Nanocrystalline anatase TiO2: a new anode material for rechargeable sodium ion batteries, Chem Commun (Camb), 49 (2013) 8973-8975.

[24] J.P. Huang, D.D. Yuan, H.Z. Zhang, Y.L. Cao, G.R. Li, H.X. Yang, X.P. Gao, Electrochemical sodium storage of $\mathrm{TiO} 2(\mathrm{~B})$ nanotubes for sodium ion batteries, Rsc Adv, 3 (2013) 12593.

[25] Y. Wang, D. Su, C. Wang, G. Wang, SnO2@MWCNT nanocomposite as a high capacity anode material for sodium-ion batteries, Electrochem Commun, 29 (2013) 8-11. 
[26] D. Su, C. Wang, H. Ahn, G. Wang, Octahedral tin dioxide nanocrystals as high capacity anode materials for Na-ion batteries, Phys Chem Chem Phys, 15 (2013) 12543-12550.

[27] L. Wu, X.H. Hu, J.F. Qian, F. Pei, F.Y. Wu, R.J. Mao, X.P. Ai, H.X. Yang, Y.L. Cao, $\mathrm{Sb}-\mathrm{C}$ nanofibers with long cycle life as an anode material for high-performance sodium-ion batteries, Energ Environ Sci, 7 (2014) 323-328.

[28] J.F. Qian, Y. Chen, L. Wu, Y.L. Cao, X.P. Ai, H.X. Yang, High capacity Na-storage and superior cyclability of nanocomposite $\mathrm{Sb} / \mathrm{C}$ anode for Na-ion batteries, Chem Commun, 48 (2012) 7070-7072.

[29] L.F. Xiao, Y.L. Cao, J. Xiao, W. Wang, L. Kovarik, Z.M. Nie, J. Liu, High capacity, reversible alloying reactions in $\mathrm{SnSb} / \mathrm{C}$ nanocomposites for $\mathrm{Na}$-ion battery applications, Chem Commun, 48 (2012) 3321-3323.

[30] T. Yamamoto, T. Nohira, R. Hagiwara, A. Fukunaga, S. Sakai, K. Nitta, S. Inazawa, Charge-discharge behavior of tin negative electrode for a sodium secondary battery using intermediate temperature ionic liquid sodium bis(fluorosulfonyl) amide-potassium bis(fluorosulfonyl)amide, J Power Sources, 217 (2012) 479-484.

[31] Y.M. Lin, P.R. Abel, A. Gupta, J.B. Goodenough, A. Heller, C.B. Mullins, Sn-Cu Nanocomposite Anodes for Rechargeable Sodium-Ion Batteries, Acs Appl Mater Inter, 5 (2013) 8273-8277. 
[32] T. Nohira, T. Ishibashi, R. Hagiwara, Properties of an intermediate temperature ionic liquid NaTFSA-CsTFSA and charge-discharge properties of $\mathrm{NaCrO} 2$ positive electrode at 423 K for a sodium secondary battery, J Power Sources, 205 (2012) 506-509.

[33] A. Fukunaga, T. Nohira, Y. Kozawa, R. Hagiwara, S. Sakai, K. Nitta, S. Inazawa, Intermediate-temperature ionic liquid NaFSA-KFSA and its application to sodium secondary batteries, J Power Sources, 209 (2012) 52-56.

[34] C.S. Ding, T. Nohira, K. Kuroda, R. Hagiwara, A. Fukunaga, S. Sakai, K. Nitta, S. Inazawa, NaFSA-C(1)C(3)pyrFSA ionic liquids for sodium secondary battery operating over a wide temperature range, J Power Sources, 238 (2013) 296-300.

[35] K. Matsumoto, Y. Okamoto, T. Nohira, R. Hagiwara, Thermal and Transport Properties of $\mathrm{Na}[\mathrm{N}(\mathrm{SO} 2 \mathrm{~F})(2)]-[\mathrm{N}-M e t h y l-\mathrm{N}$-propylpyrrolidinium][N(SO2F)(2)] Ionic Liquids for $\mathrm{Na}$ Secondary Batteries, J Phys Chem C, 119 (2015) 7648-7655.

[36] A. Fukunaga, T. Nohira, R. Hagiwara, K. Numata, E. Itani, S. Sakai, K. Nitta, S. Inazawa, A safe and high-rate negative electrode for sodium-ion batteries: Hard carbon in NaFSA-C(1)C(3)pyrFSA ionic liquid at 363 K, J Power Sources, 246 (2014) 387-391.

[37] C. Ding, T. Nohira, R. Hagiwara, K. Matsumoto, Y. Okamoto, A. Fukunaga, S. Sakai, K. Nitta, S. Inazawa, Na[FSA]-[C3C1pyrr][FSA] ionic liquids as electrolytes for sodium secondary batteries: Effects of $\mathrm{Na}$ ion concentration and operation temperature, $\mathrm{J}$ Power Sources, 269 (2014) 124-128. 
[38] S. Komaba, T. Nakayama, A. Ogata, T. Shimizu, C. Takei, S. Takada, A. Hokura, I. Nakai, Electrochemically Reversible Sodium Intercalation of Layered NaNi0.5Mn0.5O2 and NaCrO2, Ecs Transactions, 16 (2009) 43-55.

[39] C.Y. Chen, K. Matsumoto, T. Nohira, R. Hagiwara, A. Fukunaga, S. Sakai, K. Nitta, S. Inazawa, Electrochemical and structural investigation of $\mathrm{NaCrO} 2$ as a positive electrode for sodium secondary battery using inorganic ionic liquid NaFSA-KFSA, J Power Sources, 237 (2013) 52-57. 


\section{Figure Captions}

Figure 1: Charge-discharge curves of the $\mathrm{HC}$ electrode at $90{ }^{\circ} \mathrm{C}$ with a current rate of $20 \mathrm{~mA}$ $(\mathrm{g}-\mathrm{HC})^{-1}$

Figure 2: Charge-discharge curves of the $\mathrm{HC}$ electrode at -10 to $90{ }^{\circ} \mathrm{C}$ with a current rate of $20 \mathrm{~mA}(\mathrm{~g}-\mathrm{HC})^{-1}$

Figure 3: Impedance spectra of the (a) $\mathrm{Na} / \mathrm{HC}$, (b) $\mathrm{Na} / \mathrm{Na}$, and (c) $\mathrm{HC} / \mathrm{HC}$ cells at $0-90{ }^{\circ} \mathrm{C}$.

Figure 4: (a) Charge-discharge curves and (b) rate capability of the $\mathrm{HC}$ electrode at $90{ }^{\circ} \mathrm{C}$ with current rate of 20-2000 mA (g-HC) ${ }^{-1}$; (c) Comparison of rate capability of the HC electrode at 25,50 and $90^{\circ} \mathrm{C}$.

Figure 5: Cycling performance of the $\mathrm{HC}$ electrode at 25 and $90{ }^{\circ} \mathrm{C}$. Current rate: $200 \mathrm{~mA}$ $(\mathrm{g}-\mathrm{HC})^{-1}$

Figure 6: Charge-discharge curves of the $\mathrm{HC} / \mathrm{NaCrO}_{2}$ full cell at $90{ }^{\circ} \mathrm{C}$ with a current rate of $20 \mathrm{~mA}(\mathrm{~g}-\mathrm{HC})^{-1}$ 
Figures

1

2

3

4

5

6

7

8

9

10

11

12

13

14

15

16

17

18

19

20

21

22

23

24

25

26

27

28

29

30

31

32

33

34

35

36

37

38

39

40

41

42

43

44

45

46

47

48

49

50

51

52

53

54

55

56

57

58

59

60

61

62

63

64

65

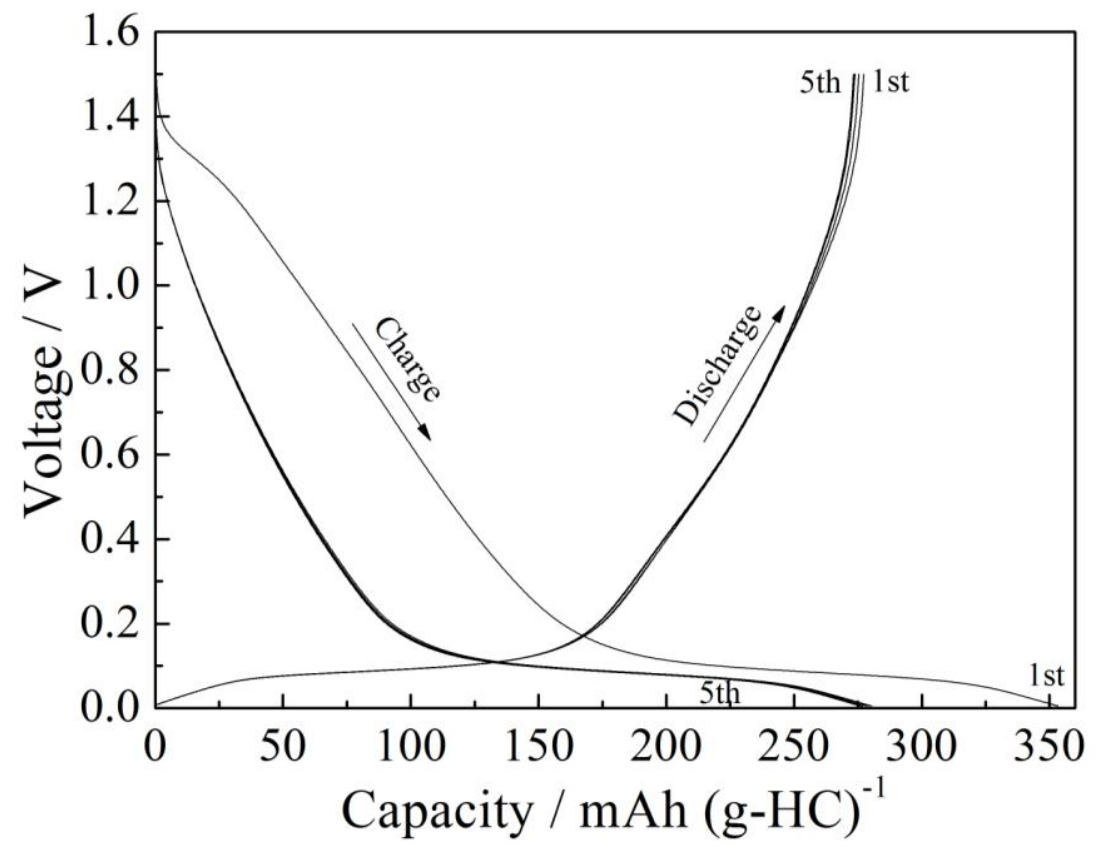

Fig. 1 Charge-discharge curves of the $\mathrm{HC}$ electrode at $90{ }^{\circ} \mathrm{C}$ with a current rate of 20 $\mathrm{mA}(\mathrm{g}-\mathrm{HC})^{-1}$ 


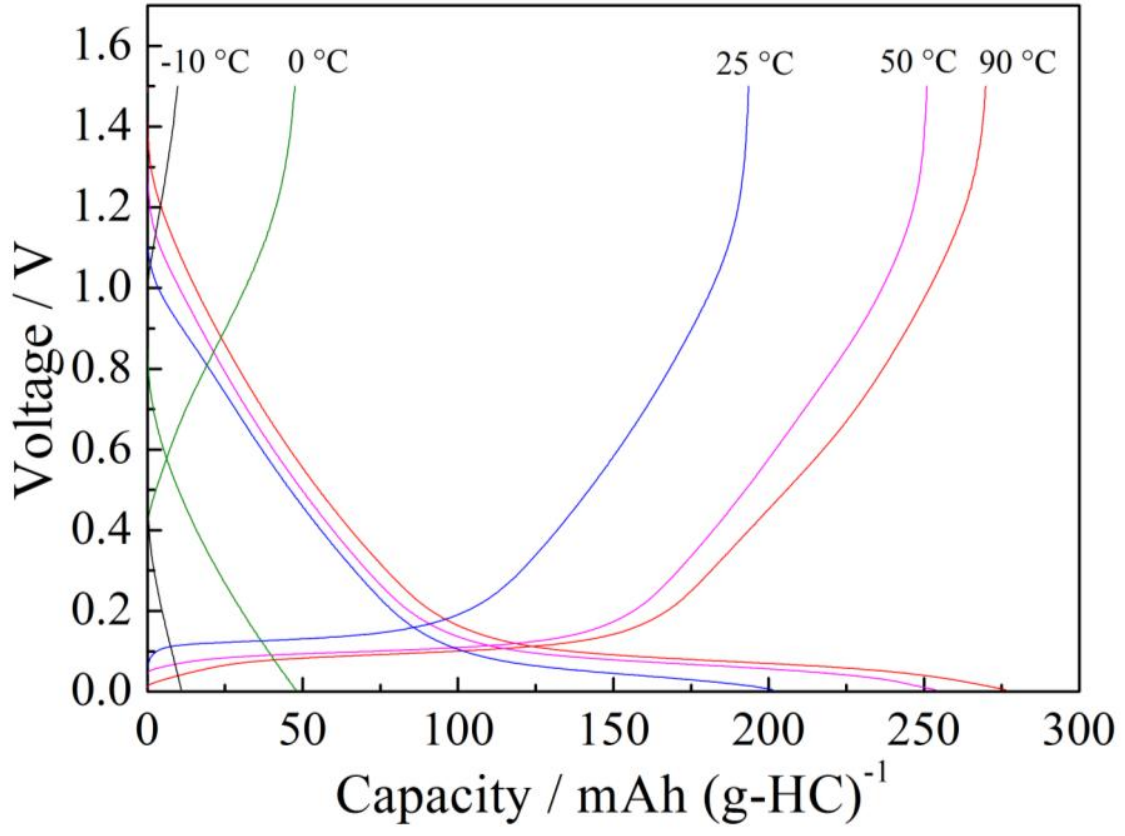

Fig. 2 Charge-discharge curves of the $\mathrm{HC}$ electrode at -10 to $90{ }^{\circ} \mathrm{C}$ with a current rate of $20 \mathrm{~mA}(\mathrm{~g}-\mathrm{HC})^{-1}$. 
(a)

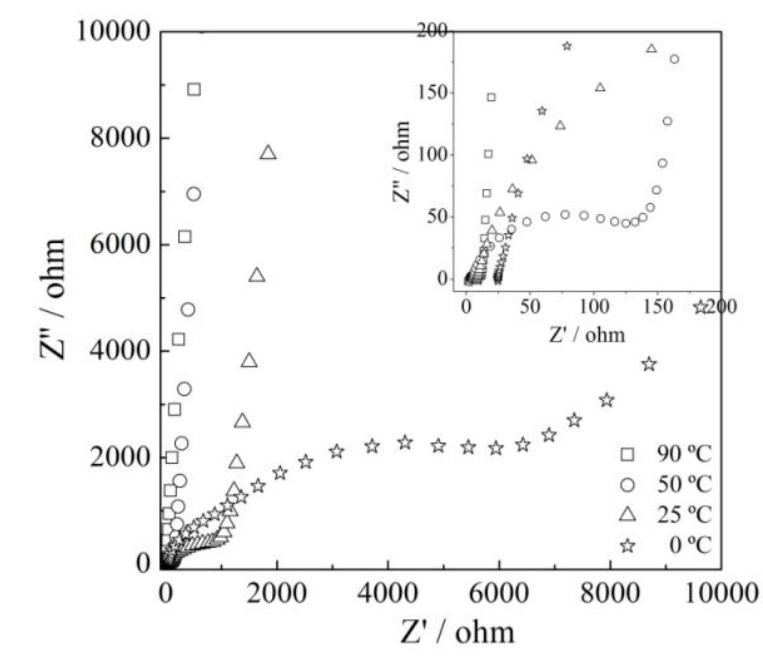

(b)

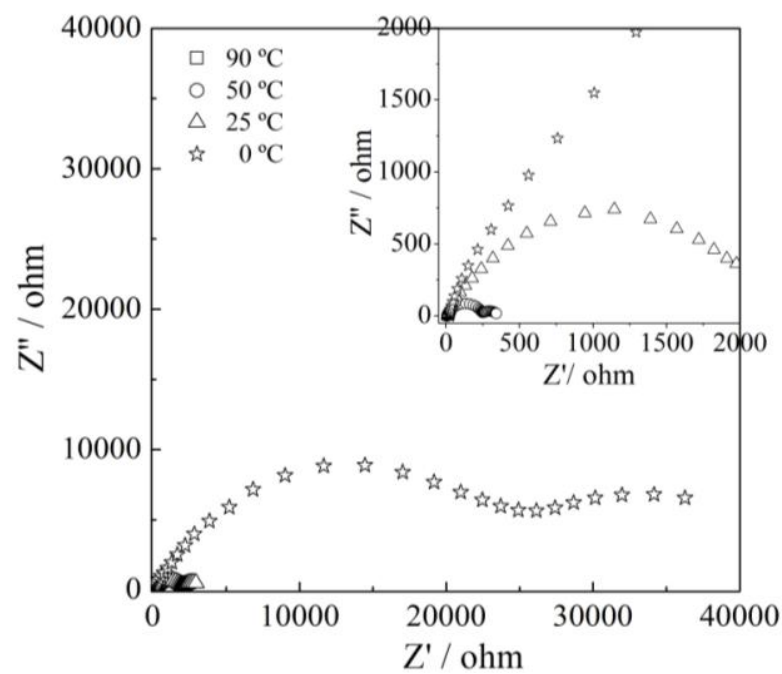

(c)

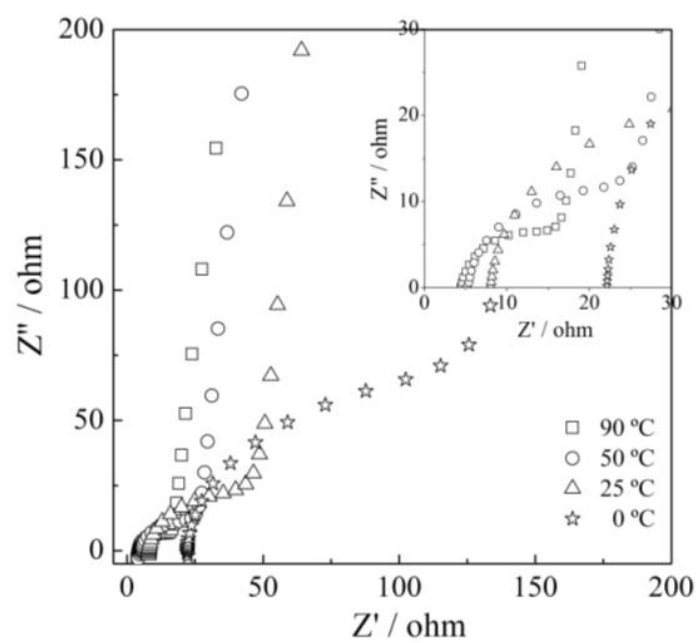

Fig. 3 Impedance spectra of the (a) $\mathrm{Na} / \mathrm{HC}$, (b) $\mathrm{Na} / \mathrm{Na}$, and (c) $\mathrm{HC} / \mathrm{HC}$ cells at $0-90{ }^{\circ} \mathrm{C}$. 
(a)

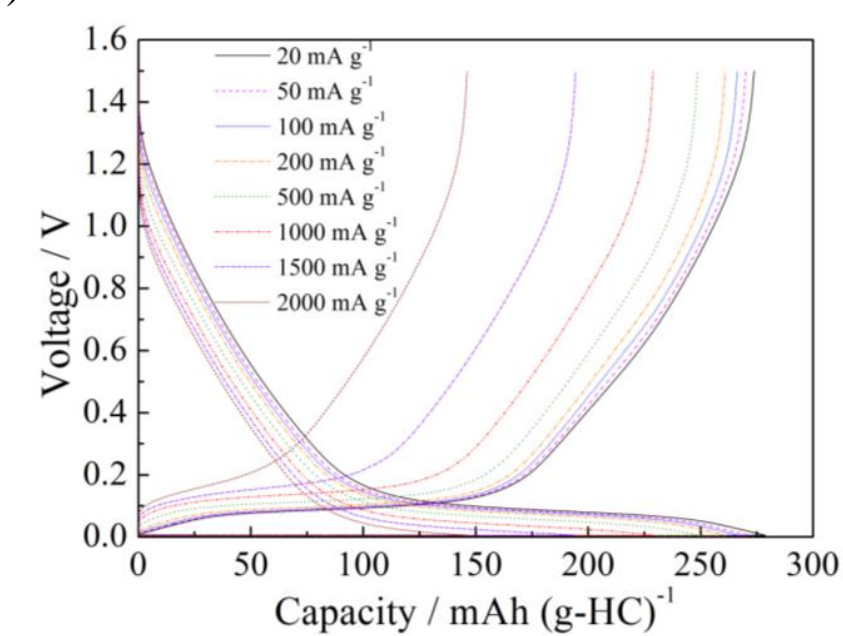

(b)

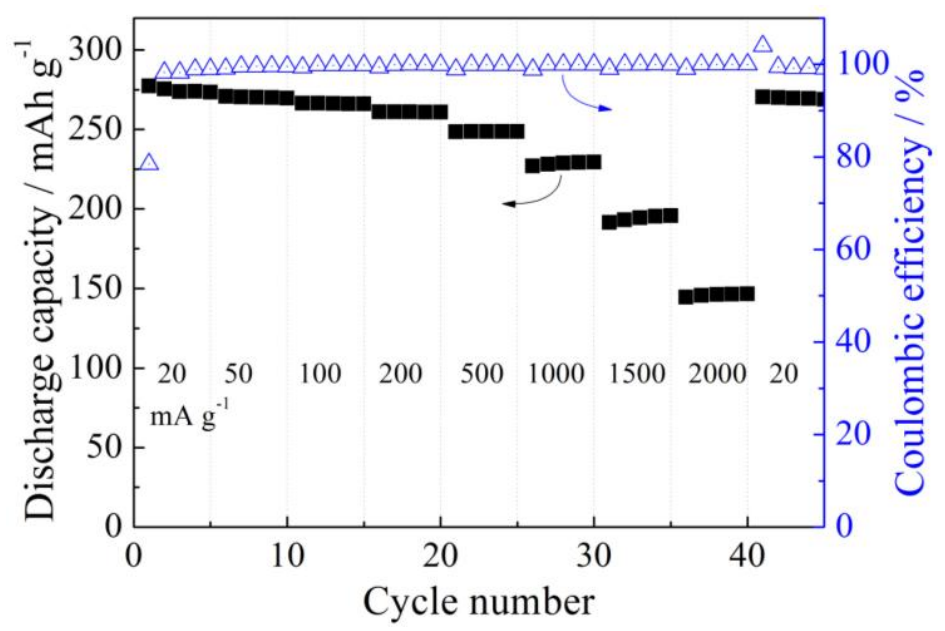

(c)

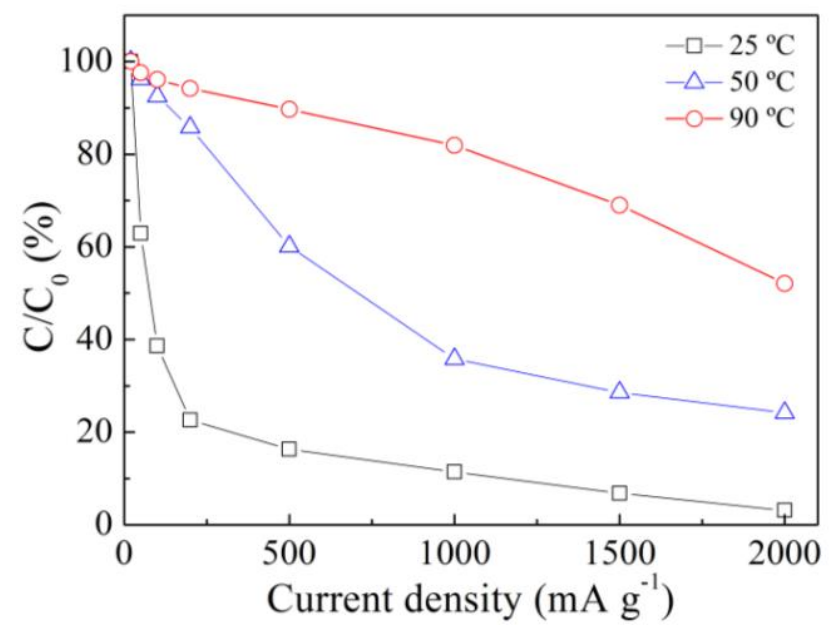

Fig. 4 (a) Charge-discharge curves and (b) rate capability of the $\mathrm{HC}$ electrode at $90{ }^{\circ} \mathrm{C}$ with current rate of $20-2000 \mathrm{~mA}(\mathrm{~g}-\mathrm{HC})^{-1}$; (c) Comparison of rate capability of the $\mathrm{HC}$ electrode at 25,50 and $90{ }^{\circ} \mathrm{C}$. 


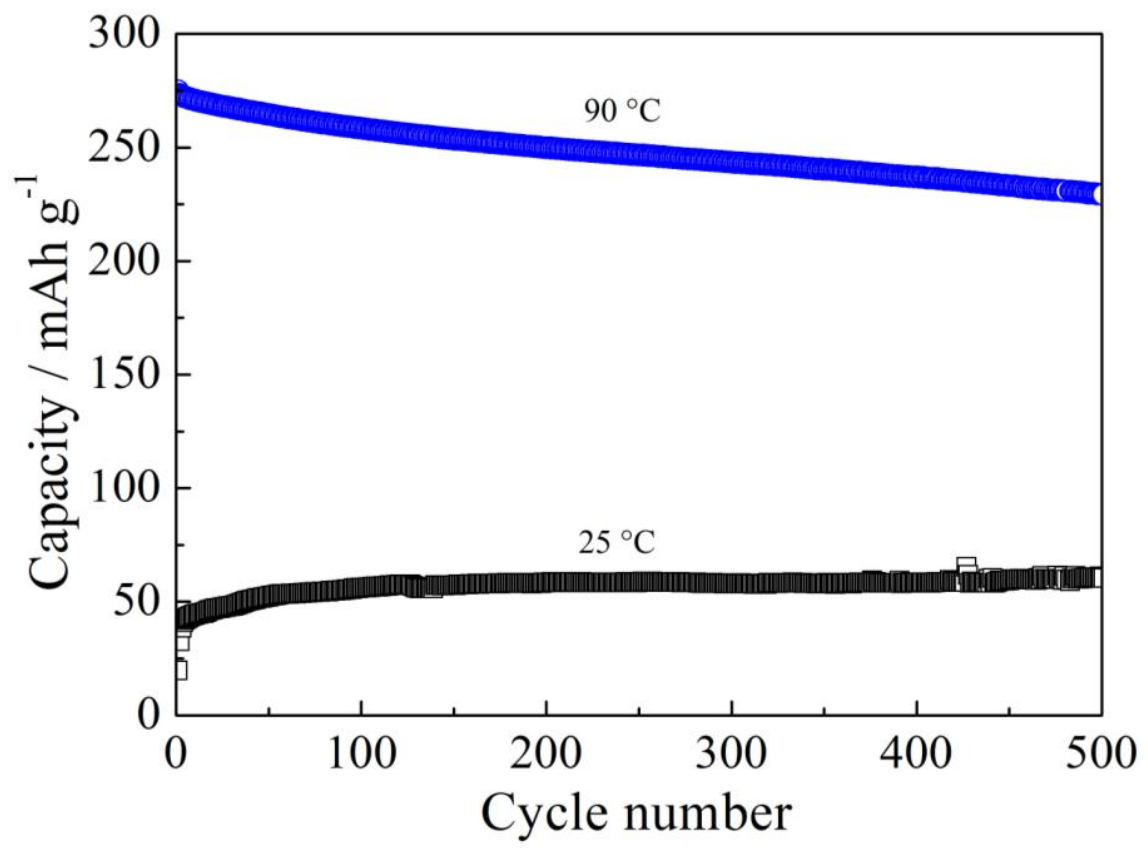

Fig. 5 Cycling performance of the $\mathrm{HC}$ electrode at 25 and $90{ }^{\circ} \mathrm{C}$. Current rate: $200 \mathrm{~mA}$ $(\mathrm{g}-\mathrm{HC})^{-1}$ 


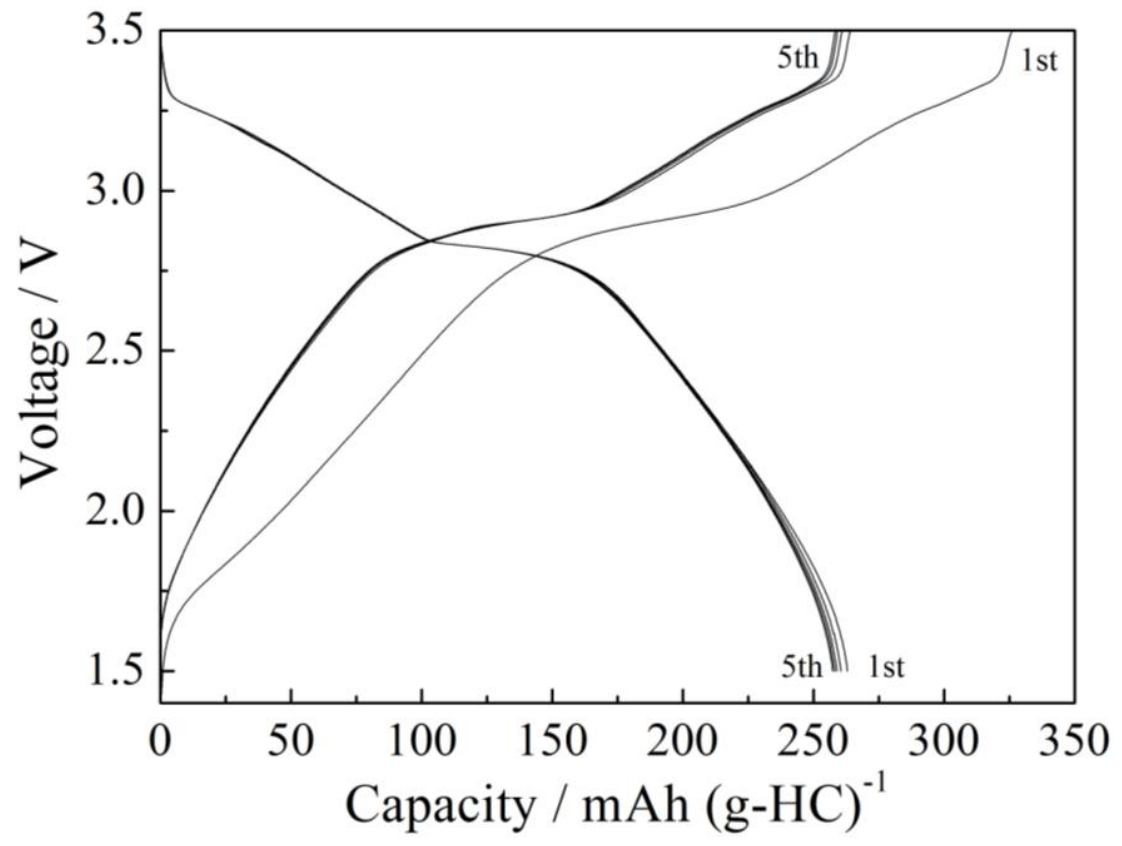

Fig. 6 Charge-discharge curves of the $\mathrm{HC} / \mathrm{NaCrO}_{2}$ full cell at $90{ }^{\circ} \mathrm{C}$ with a current rate of $20 \mathrm{~mA}(\mathrm{~g}-\mathrm{HC})^{-1}$ 